Ciência e Agrotecnologia, 42(1):7-20, Jan/Feb. 2018

http://dx.doi.org/10.1590/1413-70542018421014518

\title{
Adsorption and availability of phosphorus in response to humic acid rates in soils limed with $\mathrm{CaCO}_{3}$ or $\mathrm{MgCO}_{3}$
}

\section{Adsorção e disponibilidade de fósforo em resposta a doses de ácido húmico em solos corrigidos por $\mathrm{CaCO}_{3}$ ou $\mathrm{MgCO}_{3}$}

\author{
Henrique José Guimarães Moreira Maluf ${ }^{*}$, Carlos Alberto Silva ${ }^{1}$, Nilton Curi', \\ Lloyd Darrell Norton², Sara Dantas Rosa ${ }^{1}$
}

${ }^{1}$ Universidade Federal de Lavras/UFLA, Departamento de Ciência do Solo/DCS, Lavras, MG, Brasil

2Purdue University, Department of Agricultural and Biological Engineering, West Lafayette, Indiana, USA

${ }^{*}$ Corresponding author: maluf.henrique@yahoo.com.br

Received in May 18, 2017 and approved in July 24, 2017

\begin{abstract}
Humic acid (HA) may reduce adsorption and increase soil P availability, however, the magnitude of this effect is different when $\mathrm{Ca}^{2+}$ prevails over $\mathrm{Mg}^{2+}$ in limed soils. The objective of this study was to evaluate the effects of $\mathrm{HA} \mathrm{rates}$ and carbonate sources on the adsorption, phosphate maximum buffering capacity (PMBC), and $\mathrm{P}$ availability in two contrasting soils. Oxisol and Entisol samples were firstly incubated with the following HA rates: $0,20,50,100,200$ and $400 \mathrm{mg} \mathrm{kg}^{-1}$, combined with $\mathrm{CaCO}_{3}$ or $\mathrm{MgCO}_{3^{\prime}}$ to evaluate $\mathrm{P}$ adsorption. In sequence, soil samples were newly incubated with $\mathrm{P}\left(400 \mathrm{mg} \mathrm{kg}^{-1}\right)$ to evaluate $\mathrm{P}$ availability. The least $\mathrm{P}$ adsorption was found when $296 \mathrm{mg} \mathrm{kg}^{-1}$ of HA was added to Oxisol. Applying HA rates decreased maximum adsorption capacity, increased P binding energy to soil colloids and did not alter PMBC of Entisol. Available P contents in Oxisol increased with HA rates, but it did not change in Entisol. Choosing the right HA rate can decrease PMBC up to $40 \%$ and increase the Oxisol $\mathrm{P}$ availability by $17 \%$. Application of $\mathrm{MgCO}_{3}$ instead of $\mathrm{CaCO}_{3}$ decreased $\mathrm{P}$ adsorption in both soils. Thus, a positive correlation between $\mathrm{Ca}^{2+}$ content and $\mathrm{PMBC}$ was verified. Optimum rate of $\mathrm{HA}$ and the preponderance of $\mathrm{Mg}^{2+}$ instead of $\mathrm{Ca}^{2+}$ in soil volume fertilized with $\mathrm{P}$ are effective practices to reduce adsorption and increase P availability, especially in clayey Oxisol.
\end{abstract}

Index terms: Organic ligands; liming; humic acid-metal-P complexes; Langmuir isotherm; phosphate maximum buffering capacity.

\begin{abstract}
RESUMO
O ácido húmico (AH) pode reduzir a adsorção e aumentar a disponibilidade de P nos solos, entretanto, a magnitude desse efeito é diferente quando o $\mathrm{Ca}^{2+}$ prevalece sobre $\mathrm{Mg}^{2+}$ em solos com acidez corrigida. Objetivou-se avaliar os efeitos de doses de AH e fontes de carbonato na adsorção, fator capacidade de P máximo (FCPm) e disponibilidade de P em solos contrastantes. Amostras de Latossolo e Gleissolo foram primeiramente incubadas com as seguintes doses de $\mathrm{AH}:$ 0, 20, 50, 100, 200 e $400 \mathrm{mg} \mathrm{kg}^{-1}$, combinadas com CaCO ou $\mathrm{MgCO}_{3^{\prime}}$ para avaliar a adsorção de $\mathrm{P}$. Em sequência, as amostras de solo foram novamente incubadas com P (400 mg kg ${ }^{-1}$ ), para determinar a disponibilidade de P. A aplicação de doses de AH reduziu a capacidade máxima de adsorção, aumentou a energia de ligação do $\mathrm{P} e$ não alterou a FCPm do Gleissolo. O teor de P disponível aumentou com o acréscimo das doses de AH no Latossolo, contudo, não foram alterados no Gleissolo. A escolha correta da dose de AH reduziu a FCPm em até $40 \%$ e aumentou a disponibilidade de $\mathrm{P}$ no Latossolo em 17\%. A aplicação de $\mathrm{MgCO}_{3}$ em vez do $\mathrm{CaCO}_{3}$ reduziu a adsorção de $\mathrm{P}$ em ambos os solos. Assim, houve correlação positiva entre o teor de $\mathrm{Ca}^{2+}$ e a FCPm. A dose ótima de $\mathrm{AH}$ e a predominância de $\mathrm{Mg}^{2+}$ sobre $\mathrm{Ca}^{2+}$ no volume de solo adubado com $\mathrm{P}$ são práticas efetivas para reduzir a adsorção e aumentar a disponibilidade de P, especialmente, no Latossolo argiloso.
\end{abstract}

Termos para indexação: Ligantes orgânicos; calagem; complexos ácido húmico-metal-P; isoterma de Langmuir; fator capacidade de $\mathrm{P}$ máximo.

\section{INTRODUCTION}

Plants grown in tropical soils have low efficiency in uptake $\mathrm{P}$, since the P-fertilizer recovery rates are in the range of 5 to 25\% (Yang et al., 2013; Yu et al., 2013). Low P-fertilizer recovery is due to the specific phosphate adsorption, which rarely is returned to soil solution in highly weathered soils (Guedes et al., 2016), preventing P uptake by plants. Soil P maximum adsorption capacity (PMAC) is regulated mainly by soil $\mathrm{pH}$, particle size distribution, clay mineralogy, $\mathrm{Fe}$ and $\mathrm{Al}$ oxide contents and types, and soil oxide crystallinity (Fink et al., 2014). Among other factors, increased $\mathrm{P}$ adsorption in tropical soil is due to lower $\mathrm{pH}$ and predominance of kaolinite and $\mathrm{Fe}$ and $\mathrm{Al}$ oxides in the clay fraction (Novais; Smyth, 1999). PMAC of Brazilian soils ranges from 297 to $4,561 \mathrm{mg} \mathrm{kg}^{-1}$ in the $0.0-0.1 \mathrm{~m}$ layer, and is highly correlated with $\mathrm{Fe}$ oxide content and soil mineral 
specific surface areas (Fink et al., 2014). Compared to temperate region soils, high amounts of $\mathrm{P}$ fixed in Brazilian soils explains the elevated P-fertilizer rates used to meet crop P requirement (Teles et al., 2017).

Besides liming in the soil, humic acid (HA) use is a strategy to reduce $\mathrm{P}$ adsorption in tropical soils (Fu et al., 2013; Wang et al., 2016). According to Guan, Shang and Chen (2006), among organic compounds studied, HA was the most effective in blocking the active sites for $\mathrm{P}$ adsorption in synthetic $\mathrm{Al}$ hydroxide. HA use also reduced $\mathrm{P}$ adsorption on synthetic goethite surface, mainly when HA was applied prior to P (Fu et al., 2013). For Brazilian soils, information about optimum HA rate to reduce adsorption and increase $P$ availability along with its effect on plant nutrition and growth is not available. According to Atiyeh et al. (2002), plant growth is enhanced when HA is applied in the range of 50 to $500 \mathrm{mg} \mathrm{kg}^{-1}$.

Liming is routinely used in tropical soils to raise $\mathrm{pH}$, neutralize $\mathrm{Al}^{3+}$, supply balanced amounts of $\mathrm{Ca}^{2+}$ and $\mathrm{Mg}^{2+}$, and increase P availability (Sato; Comerford, 2005). Lime rates successively applied on soil surface of permanent crops or no-tillage areas may be high enough to cause overliming. Surface liming should be performed along with correct soil sampling to represent vertical stratification of soil acidity degree and to avoid wrong lime rate definition, otherwise surface soil layers can be alkalinized (Pádua; Silva; Melo, 2006). Low agronomic efficiency liming may also be related to limestone materials available in Minas Gerais, since most carbonates contains about $56 \%$ of $\mathrm{CaO}$ and less than $5 \%$ of $\mathrm{MgO}$ (Sampaio; Almeida, 2005). Even though liming is an effective practice to correct soil acidity, the use of limestones richer in $\mathrm{Ca}$ than in $\mathrm{Mg}$ can promote an imbalance of exchangeable $\mathrm{Ca}: \mathrm{Mg}$ ratio in soil, resulting in an improper supply of $\mathrm{Mg}^{2+}, \mathrm{K}^{+}$and ammonium-N to plants (Pádua; Silva; Melo, 2006). Nature of phosphatecalcium carbonate interaction involves initially formation of precipitates of dicalcium phosphate, which alternatively may be converted into octacalcium phosphate and even in hydroxyapatite (Perassi; Borgnino, 2014). HA added is likely to improve soil P availability (Perassi; Borgnino, 2014), increasing the recovery of applied $P$ even in calcareous soils (Delgado et al., 2002).

Addition of $\mathrm{Ca}^{2+}$ to soils increases the density of positive charges on colloid surfaces, which may contribute to form new $\mathrm{P}$ adsorption sites, favoring $\mathrm{P}$ binds through metal bridges (Guppy et al., 2005; Weng; Riemsdijk; Hiemstra, 2012; Duputel et al., 2013). Influence of $\mathrm{Ca}^{2+}$ and $\mathrm{Mg}^{2+}$ on $\mathrm{P}$ adsorption and availability in tropical soils have not been documented so far. Thus, it is important to study if adsorbed and available $\mathrm{P}$ in Brazilian soils are regulated by HA rates and carbonate sources. We hypothesized that addition of $\mathrm{HA}$ in combination with $\mathrm{MgCO}_{3}$ can increase $\mathrm{P}$ availability, mainly in clayey soils due to decreased $\mathrm{P}$ adsorption. This study was carried out to evaluate the effects of HA rates in combination with $\mathrm{CaCO}_{3}$ or $\mathrm{MgCO}_{3}$ as liming materials on $\mathrm{P}$ adsorption, phosphate maximum buffering capacity and $\mathrm{P}$ availability in two soils with contrasting particle size distribution, mineralogy and organic matter content.

\section{MATERIAL AND METHODS}

\section{Soils}

Samples from an Oxisol and Entisol were collected at the $0-20 \mathrm{~cm}$ depth under native vegetation in Lavras, MG, Brazil. Main chemical, physical and mineralogical soil properties are shown in Table 1.

Total $\mathrm{P}$ and $\mathrm{Fe}$ and $\mathrm{Al}$ oxides contents of the clay fraction were determined by sulfuric acid digestion (Vettori, 1969). Less crystalline $\mathrm{Al}$ and $\mathrm{Fe}$ oxides were determined using a single extraction with a $0.2 \mathrm{~mol} \mathrm{~L}^{-1}$ ammonium oxalate solution at pH 3 (McKeague, 1978), and the more crystalline $\mathrm{Al}$ and $\mathrm{Fe}$ oxides were determined by four successive extractions with sodium dithionite-citratebicarbonate (Mehra; Jackson, 1960). Al and Fe contents were quantified by inductively coupled plasma-optical emission spectrometry (ICP-OES, Spectro Analytical Instruments, Germany). Minerals in soil clay fraction were identified by X-ray diffractometry (Figure 1), using a Bruker Diffractometer, DZ phaser, with a vertical goniometer and an angular velocity of $0.5^{\circ} 2 \theta \mathrm{min}^{-1}$, range from 10 to $50^{\circ} 2 \theta$, equipped with $\mathrm{Cu}$ tube and $\mathrm{Ni}$ filter, operating at $20 \mathrm{kV}$ and $40 \mathrm{~mA}$, employing the powder method with halite as an internal standard.

\section{Humic acid characterization}

Humic acid (HA) was extracted from leonardite through the use of a $0.5 \mathrm{~mol} \mathrm{~L}^{-1} \mathrm{KOH}$ solution, and, in sequence, purified, following the method recommended by the International Humic Substances Society (Swift, 1996). HA C content $\left(372 \mathrm{~g} \mathrm{~kg}^{-1}\right)$ was measured in an elemental automated analyzer (Elementar, Vario Cube model, Germany). HA also contained $0.8 \mathrm{~g} \mathrm{~kg}^{-1} \mathrm{Ca}$ and $2.3 \mathrm{~g} \mathrm{~kg}^{-1} \mathrm{Mg}$, both quantified by ICP-OES. Phosphorus was not present in the HA sample. Values of $\mathrm{pH}$ (9.7) and electrical conductivity $\left(10.2 \mathrm{mS} \mathrm{cm}^{-1}\right)$ were both measured in a HA:water ratio of 1:5 (w/v). Humic acid E4/E6 ratio was 4.9 , which was determined after dissolving $\mathrm{HA}$ in a $0.05 \mathrm{~mol} \mathrm{~L}^{-1} \mathrm{NaHCO}_{3}$; subsequently, the absorbance of $\mathrm{C}$ 
Table 1: Properties of the soil samples (0-0.2 m) investigated, under native vegetation.

\begin{tabular}{|c|c|c|}
\hline Soil property & Oxisol $^{1}$ & Entisol $^{1}$ \\
\hline $\mathrm{pH}$ in $\mathrm{H}_{2} \mathrm{O}, 1: 2.5(\mathrm{v} / \mathrm{v})$ & 4.7 & 5.1 \\
\hline Total P of the clay fraction $\left(\mathrm{mg} \mathrm{kg}^{-1}\right)$ & 165.8 & 87.3 \\
\hline Available P - M1 (mg kg-1) & 1.5 & 1.7 \\
\hline $\mathrm{Ca}^{2+}\left(\mathrm{cmol} \mathrm{kg}^{-1}\right)$ & 0.1 & 0.5 \\
\hline $\mathrm{Mg}^{2+}\left(\mathrm{cmol}_{\mathrm{c}}^{\mathrm{c}} \mathrm{kg}^{-1}\right)$ & 0.1 & 0.3 \\
\hline $\mathrm{Al}^{3+}\left(\mathrm{cmol} \mathrm{kg}^{-1}\right)$ & 1.0 & 0.5 \\
\hline $\mathrm{H}+\mathrm{Al}\left(\mathrm{cmol}_{\mathrm{c}} \mathrm{kg}^{-1}\right)$ & 7.1 & 4.1 \\
\hline CEC at pH $7\left(\mathrm{cmol} \mathrm{kg}^{-1}\right)$ & 7.7 & 5.9 \\
\hline Total C $\left(\mathrm{g} \mathrm{kg}^{-1}\right)$ & 23.3 & 8.6 \\
\hline Rem-P $\left(\mathrm{mg} \mathrm{L}^{-1}\right)$ & 19.2 & 31.5 \\
\hline PMAC $\left(\mathrm{mg} \mathrm{g}^{-1}\right)$ & 0.8 & 0.5 \\
\hline Clay $\left(\mathrm{g} \mathrm{kg}^{-1}\right)$ & 500.0 & 250.0 \\
\hline Silt $\left(\mathrm{g} \mathrm{kg}^{-1}\right)$ & 130.0 & 160.0 \\
\hline Sand $\left(\mathrm{g} \mathrm{kg}^{-1}\right)$ & 370.0 & 590.0 \\
\hline Total $\mathrm{Fe}_{2} \mathrm{O}_{3}\left(\mathrm{~g} \mathrm{~kg}^{-1}\right)$ & 49.7 & 10.1 \\
\hline Total $\mathrm{Al}_{2} \mathrm{O}_{3}\left(\mathrm{~g} \mathrm{~kg}^{-1}\right)$ & 214.7 & 59.0 \\
\hline Dithionite $\mathrm{Fe}_{2} \mathrm{O}_{3}\left(\mathrm{~g} \mathrm{~kg}^{-1}\right)$ & 49.6 & 7.3 \\
\hline Dithionite $\mathrm{Al}_{2} \mathrm{O}_{3}\left(\mathrm{~g} \mathrm{~kg}^{-1}\right)$ & 10.1 & 2.5 \\
\hline Oxalate $\mathrm{Fe}_{2} \mathrm{O}_{3}\left(\mathrm{~g} \mathrm{~kg}^{-1}\right)$ & 0.4 & 0.8 \\
\hline Oxalate $\mathrm{Al}_{2} \mathrm{O}_{3}\left(\mathrm{~g} \mathrm{~kg}^{-1}\right)$ & 1.2 & 1.2 \\
\hline Minerals of the clay fraction & $\mathrm{Kt}>\mathrm{Gb}>\mathrm{Gt}>\mathrm{Hm}>\mathrm{Mh}$ & $\mathrm{Kt}>\mathrm{Gb}>\mathrm{Hm}>\mathrm{Mh}>\mathrm{Gt}$ \\
\hline
\end{tabular}

${ }^{1}$ Soil Taxonomy; $\mathrm{M} 1$ = available $\mathrm{P}$ extracted by Mehlich-1 solution; $\mathrm{CEC}=$ cation exchange capacity; Rem-P = Remaining P; $\mathrm{PMAC}$ = phosphate maximum adsorption capacity; $\mathrm{Kt}=$ kaolinite; $\mathrm{Gb}=$ gibbsite; $\mathrm{Gt}=$ goethite; $\mathrm{Hm}$ = hematite; $\mathrm{Mh}=$ maghemite .

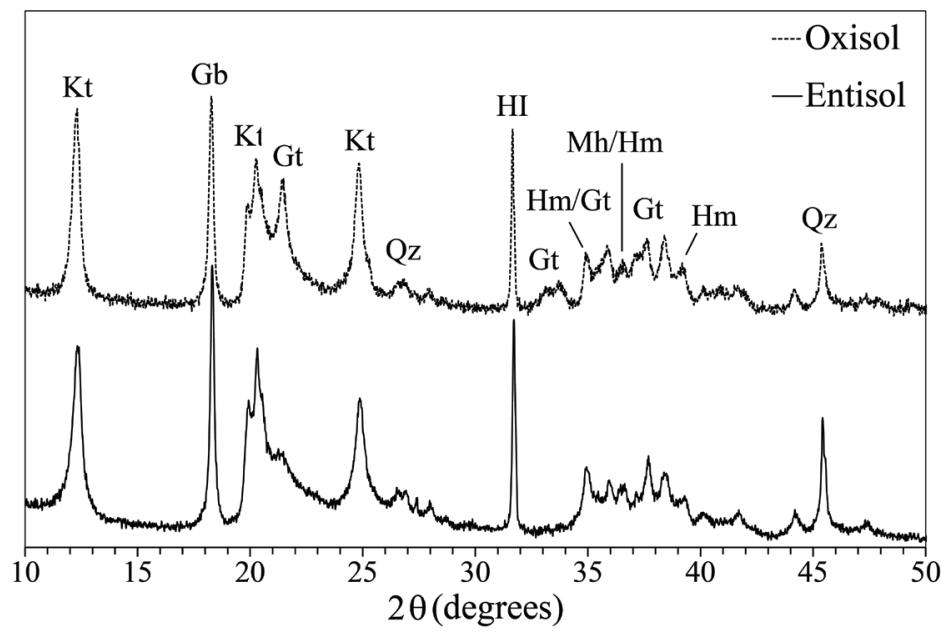

Figure 1: X-ray diffractogram of Na-saturated clay fraction of Oxisol and Entisol samples. Symbols above the peaks represent the minerals: Kt (kaolinite), Gb (gibbsite), Gt (goethite), Qz (quartz), HI (halite) (internal standard), $\mathrm{Hm}$ (hematite), Mh (maghemite). 
chemical groups in HA was measured, respectively, at 465 and $665 \mathrm{~nm}$ with a UV-visible spectrophotometer, according to Reddy et al. (2014). E4/E6 ratio values inferior or equal to 5 are typically assigned to HA samples, while values greater than 5 are routinely related to fulvic acid samples (Reddy et al., 2014). Spectroscopic features from HA were recorded using the attenuated total reflection Fourier transform infrared (ATR-FTIR) technique, in a Bruker series vertex 70v machine. Spectrum bands were recorded in the range of 4000 to $400 \mathrm{~cm}^{-1}$ with a resolution of 2 $\mathrm{cm}^{-1}$ (Figure 2). Assignments of chemical organic found in the HA were interpreted following library described by Stevenson (1994), as follows. Absorption ATR-FTIR bands in the range between 3400 and $3200 \mathrm{~cm}^{-1}$, with a peak at $3332 \mathrm{~cm}^{-1}$, are typical of $\mathrm{OH}$ groups. Bands at 2918 and 2850 $\mathrm{cm}^{-1}$ were assigned to aliphatic $\mathrm{CH}$. The absorption band at $1574 \mathrm{~cm}^{-1}$ can be assigned to $\mathrm{C}=\mathrm{C}$ aromatic structures, and at $1365 \mathrm{~cm}^{-1}$ to $\mathrm{C}_{-} \mathrm{CH}_{3}$ groups bending.

\section{Study description}

Surface (0-0.2 m) samples of Oxisol and Entisol were incubated with different HA rates and carbonate sources. In both cases, a completely randomized design was adopted with four replicates. Two experiments, one with Oxisol and the other with Entisol samples, were carried out simultaneously. A $6 \times 2$ factorial scheme was adopted, since six HA rates $(0 ; 20 ; 50 ; 100 ; 200$ and 400 $\mathrm{mg} \mathrm{kg}{ }^{-1}$ ) were combined with two carbonate sources $\left(\mathrm{CaCO}_{3}\right.$ and $\left.\mathrm{MgCO}_{3}\right)$. Each experimental plot consisted of $150 \mathrm{~g}$ of sieved $(<2 \mathrm{~mm})$ dry soil that were stored in a $200 \mathrm{~mL}$ polyethylene container. For each soil, two sequential incubations were carried out: firstly, $\mathrm{CaCO}_{3}$ or $\mathrm{MgCO}_{3}$ were mixed with each $\mathrm{HA}$ rate already described, which were incubated with soil samples during thirty days. During this first incubation, soil moisture was kept close to $60 \%$ of the soil field capacity. In the second incubation, $400 \mathrm{mg} \mathrm{kg}{ }^{-1}$ of $\mathrm{P}$ (reagent grade $\mathrm{KH}_{2} \mathrm{PO}_{4}$ ) were added and mixed to dried and sieved $(<2 \mathrm{~mm})$ soil samples, previously incubated with carbonate and HA rates, which were again incubated for another thirty days under the same incubation conditions already described for the first incubation.

Soil acidity was corrected aiming to reach a $\mathrm{pH}$ in water around 6 and to increase soil $\mathrm{Ca}^{2+}$ with $\mathrm{CaCO}_{3}$, and $\mathrm{Mg}^{2+}$ contents with $\mathrm{MgCO}_{3}$. Carbonate rates were estimated by soil acidity neutralization curves (soil $\mathrm{pH}$ as a function of increasing carbonate rates) described in Kaminski et al. (2002). Thus, concentration of carbonate applied in Oxisol was $1.26 \mathrm{~g} \mathrm{~kg}^{-1} \mathrm{CO}_{3}\left(2.10 \mathrm{~g} \mathrm{~kg}^{-1}\right.$ $\mathrm{CaCO}_{3}$ or $1.77 \mathrm{~g} \mathrm{~kg}^{-1} \mathrm{MgCO}_{3}$ ); in Entisol samples was added $0.77 \mathrm{~g} \mathrm{~kg}^{-1} \mathrm{CO}_{3}\left(1.28 \mathrm{~g} \mathrm{~kg}^{-1} \mathrm{CaCO}_{3}\right.$ or $1.08 \mathrm{~g} \mathrm{~kg}^{-1}$ $\mathrm{MgCO}_{3}$ ). Main soil chemical properties after incubations are shown in Table 2.

\section{Phosphorus adsorption and availability}

After first incubation, $2.5 \mathrm{~g}$ of dried soil were stored in $50 \mathrm{ml}$ tubes and mixed with $25 \mathrm{~mL}$ of $0.01 \mathrm{~mol}$ $\mathrm{L}^{-1} \mathrm{CaCl}_{2}$ solution to perform the $\mathrm{P}$ adsorption study. Oxisol samples were mixed with solutions containing eleven $\mathrm{P}$ concentrations (reagent grade $\mathrm{KH}_{2} \mathrm{PO}_{4}$ ), as

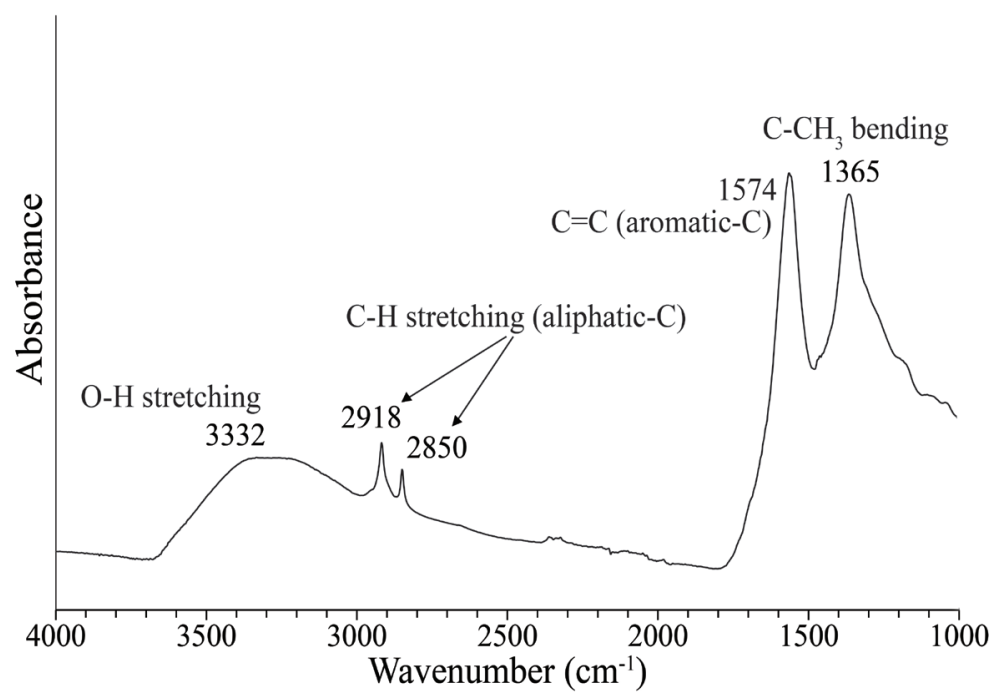

Figure 2: ATR-FTIR spectrum and the main organic chemical groups recorded for the humic acid sample extracted from leonardite. 
follows: $0,5,11,16,27,38,49,60,77,93$ and $110 \mathrm{mg}$ $\mathrm{L}^{-1}$. Entisol samples were mixed with $0,4,8,12,20,28$, $36,44,56,68$ and $80 \mathrm{mg} \mathrm{L}^{-1}$ of P. P concentration in the mixing solutions were based on remaining $P$ values of each soil, following methodology proposed by Alvarez et al. (2000). After mixing soil with P solutions and shaking them for 24 hours, tubes with soil were centrifuged for 5 minutes at 3,000 rpm and the supernatant was filtered.
$\mathrm{P}$ content in the filtered solutions was determined in a UV-visible spectrophotometer, according to Murphy and Riley (1962).

The nonlinear model of the Langmuir isotherm (Equation 1) was fitted to $\mathrm{P}$ adsorption data set to estimate $\mathrm{P}$ maximum adsorption capacity (PMAC) and $\mathrm{P}$ binding energy $(\mathrm{BE})$, using the nonlinear regression model described below:

Table 2: Chemical properties of soil samples limed with $\mathrm{CaCO}_{3}$ or $\mathrm{MgCO}_{3}$ and treated with increasing humic acid (HA) rates, after incubations.

\begin{tabular}{|c|c|c|c|c|c|c|}
\hline \multirow{3}{*}{ Soil property } & \multicolumn{6}{|c|}{ Oxisol $^{1}$} \\
\hline & \multicolumn{6}{|c|}{ HA rate $\left(\mathrm{mg} \mathrm{kg}^{-1}\right)$} \\
\hline & 0 & 20 & 50 & 100 & 200 & 400 \\
\hline & \multicolumn{6}{|c|}{$\mathrm{CaCO}_{3}$} \\
\hline $\mathrm{pH}$ in $\mathrm{H}_{2} \mathrm{O}, 1: 2.5(\mathrm{v} / \mathrm{v})$ & $6.4 \pm 0.05$ & $6.4 \pm 0.02$ & $6.3 \pm 0.03$ & $6.4 \pm 0.02$ & $6.4 \pm 0.02$ & $6.5 \pm 0.02$ \\
\hline $\mathrm{Ca}^{2+}\left(\mathrm{cmol} \mathrm{kg}^{-1}\right)$ & $3.1 \pm 0.08$ & $2.9 \pm 0.06$ & $2.9 \pm 0.02$ & $2.8 \pm 0.03$ & $2.7 \pm 0.04$ & $2.7 \pm 0.08$ \\
\hline $\mathrm{Mg}^{2+}\left(\mathrm{cmol} \mathrm{kg}^{-1}\right)$ & $0.1 \pm 0.01$ & $0.1 \pm 0.01$ & $0.1 \pm 0.01$ & $0.1 \pm 0.01$ & $0.1 \pm 0.01$ & $0.1 \pm 0.01$ \\
\hline CEC at $\mathrm{pH} 7\left(\mathrm{cmol} \mathrm{kg}^{-1}\right)$ & $7.2 \pm 0.19$ & $6.8 \pm 0.06$ & $6.6 \pm 0.12$ & $6.6 \pm 0.12$ & $6.8 \pm 0.10$ & $6.9 \pm 0.15$ \\
\hline \multirow[t]{2}{*}{ Total C $\left(\mathrm{g} \mathrm{kg}^{-1}\right)^{\mathrm{c}}$} & $19.5 \pm 0.11$ & $19.5 \pm 0.06$ & $20.2 \pm 0.08$ & $20.4 \pm 0.08$ & $19.7 \pm 0.13$ & $18.1 \pm 0.08$ \\
\hline & \multicolumn{6}{|c|}{$\mathrm{MgCO}_{3}$} \\
\hline $\mathrm{pH}$ in $\mathrm{H}_{2} \mathrm{O}, 1: 2.5(\mathrm{v} / \mathrm{v})$ & $6.4 \pm 0.03$ & $6.2 \pm 0.12$ & $6.1 \pm 0.03$ & $6.4 \pm 0.05$ & $6.4 \pm 0.02$ & $6.4 \pm 0.04$ \\
\hline $\mathrm{Ca}^{2+}\left(\mathrm{cmol} \mathrm{kg}^{-1}\right)$ & $0.1 \pm 0.01$ & $0.1 \pm 0.01$ & $0.1 \pm 0.01$ & $0.1 \pm 0.01$ & $0.1 \pm 0.01$ & $0.1 \pm 0.01$ \\
\hline $\mathrm{Mg}^{2+}\left(\mathrm{cmol} \mathrm{kg}^{-1}\right)$ & $2.9 \pm 0.03$ & $2.7 \pm 0.02$ & $2.8 \pm 0.12$ & $2.8 \pm 0.03$ & $2.7 \pm 0.12$ & $2.7 \pm 0.07$ \\
\hline CEC at $\mathrm{pH} 7\left(\mathrm{cmol}_{\mathrm{c}} \mathrm{kg}^{-1}\right)$ & $7.0 \pm 0.08$ & $7.3 \pm 0.23$ & $7.3 \pm 0.18$ & $7.2 \pm 0.17$ & $7.1 \pm 0.23$ & $7.2 \pm 0.19$ \\
\hline \multirow[t]{4}{*}{ Total C $\left(\mathrm{g} \mathrm{kg}^{-1}\right)$} & $17.4 \pm 0.08$ & $17.9 \pm 0.10$ & $16.3 \pm 0.06$ & $18.3 \pm 0.11$ & $17.6 \pm 0.06$ & $17.9 \pm 0.09$ \\
\hline & \multicolumn{6}{|c|}{ Entisol $^{1}$} \\
\hline & \multicolumn{6}{|c|}{ HA rate $\left(\mathrm{mg} \mathrm{kg}^{-1}\right)$} \\
\hline & 0 & 20 & 50 & 100 & 200 & 400 \\
\hline & \multicolumn{6}{|c|}{$\mathrm{CaCO}_{3}$} \\
\hline $\mathrm{pH}$ in $\mathrm{H}_{2} \mathrm{O}, 1: 2.5(\mathrm{v} / \mathrm{v})$ & $6.2 \pm 0.05$ & $6.3 \pm 0.05$ & $6.3 \pm 0.02$ & $6.3 \pm 0.04$ & $6.3 \pm 0.04$ & $6.3 \pm 0.05$ \\
\hline $\left.\mathrm{Ca}^{2+}\left(\mathrm{cmol} \mathrm{kg}_{c}\right)^{-1}\right)$ & $2.9 \pm 0.08$ & $2.7 \pm 0.03$ & $2.8 \pm 0.02$ & $2.6 \pm 0.03$ & $2.7 \pm 0.02$ & $2.7 \pm 0.02$ \\
\hline $\mathrm{Mg}^{2+}\left(\mathrm{cmol} \mathrm{kg}^{-1}\right)$ & $0.2 \pm 0.03$ & $0.2 \pm 0.03$ & $0.2 \pm 0.03$ & $0.1 \pm 0.02$ & $0.1 \pm 0.02$ & $0.1 \pm 0.02$ \\
\hline $\mathrm{CEC}$ at $\mathrm{pH} 7\left(\mathrm{cmol}_{\mathrm{c}} \mathrm{kg}^{-1}\right)$ & $6.4 \pm 0.12$ & $6.5 \pm 0.07$ & $6.6 \pm 0.07$ & $6.6 \pm 0.15$ & $6.6 \pm 0.11$ & $6.5 \pm 0.04$ \\
\hline \multirow[t]{2}{*}{ Total C $\left(\mathrm{g} \mathrm{kg}^{-1}\right)$} & $7.1 \pm 0.03$ & $7.3 \pm 0.05$ & $7.4 \pm 0.06$ & $7.0 \pm 0.05$ & $7.6 \pm 0.06$ & $7.6 \pm 0.03$ \\
\hline & \multicolumn{6}{|c|}{$\mathrm{MgCO}_{3}$} \\
\hline $\mathrm{pH}$ in $\mathrm{H}_{2} \mathrm{O}, 1: 2.5(\mathrm{v} / \mathrm{v})$ & $6.3 \pm 0.06$ & $6.2 \pm 0.03$ & $6.3 \pm 0.02$ & $6.3 \pm 0.02$ & $6.3 \pm 0.08$ & $6.3 \pm 0.02$ \\
\hline $\mathrm{Ca}^{2+}\left(\mathrm{cmol} \mathrm{kg}^{-1}\right)$ & $0.3 \pm 0.02$ & $0.2 \pm 0.02$ & $0.2 \pm 0.03$ & $0.3 \pm 0.01$ & $0.3 \pm 0.01$ & $0.3 \pm 0.02$ \\
\hline $\mathrm{Mg}^{2+}\left(\mathrm{cmol} \mathrm{kg}^{-1}\right)$ & $3.0 \pm 0.04$ & $3.1 \pm 0.05$ & $2.7 \pm 0.07$ & $2.6 \pm 0.03$ & $2.6 \pm 0.03$ & $2.5 \pm 0.03$ \\
\hline CEC at pH $7\left(\mathrm{cmol} \mathrm{kg}^{-1}\right)$ & $6.0 \pm 0.11$ & $6.3 \pm 0.21$ & $6.3 \pm 0.05$ & $6.7 \pm 0.07$ & $6.8 \pm 0.12$ & $6.6 \pm 0.20$ \\
\hline Total C $\left(\mathrm{g} \mathrm{kg}^{-1}\right)$ & $7.3 \pm 0.03$ & $7.3 \pm 0.03$ & $7.0 \pm 0.05$ & $7.4 \pm 0.09$ & $7.0 \pm 0.05$ & $6.9 \pm 0.10$ \\
\hline
\end{tabular}

'Soil Taxonomy. 
$x / m=(P M A C x B E x C) /(1+B E x C)$

Where, $x / m$ is the adsorbed $\mathrm{P}\left(\mathrm{mg} \mathrm{g}^{-1}\right), P M A C$ is the $\mathrm{P}$ maximum adsorption capacity $\left(\mathrm{mg} \mathrm{g}^{-1}\right), B E$ is the binding energy $\left(\mathrm{L} \mathrm{mg}^{-1}\right)$, as soil affinity parameter for $\mathrm{P}$ and $C$ is the concentration of $\mathrm{P}$ in the equilibrium solution $\left(\mathrm{mg} \mathrm{L}^{-1}\right)$. Based on the parameters generated by the Langmuir isotherm (PMAC and $\mathrm{BE}$ ), soil $\mathrm{P}$ maximum buffering capacity (PMBC) (Equation 2) was calculated as the maximum slope of the Langmuir equation, evaluated at $C=0$, according to Holford and Mattingly (1976), as follows:

$P M B C=P M A C x B E$

Where, $P M B C$ is the soil $\mathrm{P}$ maximum buffering capacity $\left(\mathrm{L} \mathrm{g}^{-1}\right), P M A C$ is the $\mathrm{P}$ adsorption maximum capacity ( $\mathrm{mg}$ $\left.\mathrm{g}^{-1}\right)$ and $B E$ is the binding energy $\left(\mathrm{L} \mathrm{mg}^{-1}\right)$.

After the second incubation of soil with $400 \mathrm{mg} \mathrm{kg}^{-1}$ of $\mathrm{P}$, soil samples of each treatment were air-dried and sieved $(<2 \mathrm{~mm})$ to evaluate available $\mathrm{P}$ contents by ionic exchange resin (Raij; Quaggio, 2001) and Mehlich-1 soil tests. For both soil tests, the extracted $\mathrm{P}$ was determined in an UV-visible spectrophotometer (Murphy; Riley, 1962). Soil Ca ${ }^{2+}$ and $\mathrm{Mg}^{2+}$ were extracted by a $1 \mathrm{~mol} \mathrm{~L}^{-1} \mathrm{KCl}$ solution and determined by atomic absorption spectrophotometry (Silva, 2009).

\section{Statistical analysis}

Data were submitted to analysis of variance and means were compared using the $\mathrm{F}$ test $(p<0.05)$. Regression analyses were performed to evaluate PMAC, BE, PMBC and soil available $\mathrm{P}$ over HA rates. Exchangeable contents of $\mathrm{Ca}^{2+}$ and $\mathrm{Mg}^{2+}$ were correlated with PMBC. In all statistical steps, $R$ program 3.0.3 version was employed and the ExpDes package was used (Ferreira; Cavalcanti; Nogueira, 2013). Choosing of the regression model that best fit to data set was based on the significance of the mathematical equation parameters $(p<0.05)$ and in the equation with the highest adjusted coefficient of determination $\left(\mathrm{R}^{2}\right)$.

\section{RESULTS AND DISCUSSION}

\section{Phosphate adsorption}

Langmuir isotherm model was adjusted to soil $\mathrm{P}$ adsorption data set, and changes in adsorption patterns were observed for the humic acid (HA) rates combined with carbonate sources in both Oxisol and Entisol (Figure 3) samples. Differences in magnitude of P adsorption between the two studied soils are mainly related with particle size distribution (Table 1) and mineralogy of the clay fraction (Figure 1). Thus, greater clay, kaolinite (higher intensity in the X-ray diffractograms) and goethite (main diffraction peak at $4.15 \AA-21.38^{\circ} 2 \theta$ ) contents in Oxisol than in Entisol explain the differential $\mathrm{P}$ adsorption patterns between soils. For Brazilian soils, different studies have reported the role played by clay and its minerals in controlling $\mathrm{P}$ adsorption (Fink et al., 2014; Guedes et al., 2016; Teles et al., 2017). In addition, goethite tends to adsorb more $\mathrm{P}$ than hematite due to greater specific surface area and rugged surface of the first oxide (Wang et al., 2016).

Phosphorus maximum adsorption capacity (PMAC) values showed in Table 1 are greater than values verified in the not-HA-treated Oxisol (Figure 4) and Entisol (Figure 5) samples. Decrease in PMAC values is explained by liming (Table 2), since minerals with variable charges dominate both soils. As soil $\mathrm{pH}$ increased, higher negative charges density is found on soil colloids along with decreased $\mathrm{P}$ adsorption (Sato; Comerford, 2005; Benício et al., 2017). PMAC reduction was more pronounced in Oxisol than in Entisol due to greater difference between initial $\mathrm{pH}$ and $\mathrm{pH}$ reached after liming along with the different clay contents of the two soils.

PMAC, binding energy (BE) and $\mathrm{P}$ maximum buffering capacity (PMBC) of both soils were not significantly affected by the HA rate-carbonate source interaction $(p>0.05)$. Thus, the factors studied were isolated to evaluate the separate influence of the HA rates on PMAC, BE and PMBC, both in Oxisol (Figure 4) and in Entisol (Figure 5) samples. In Oxisol, PMAC and P-BE were reduced over HA rates, and a quadratic model was the best equation fitted to the data set. When HA was applied at the rate of $332 \mathrm{mg} \mathrm{kg}^{-1}$, PMAC was reduced by $16 \%$. PMAC reduction verified in HA-treated soils prevented $198 \mathrm{~kg} \mathrm{ha}^{-1} \mathrm{P}$ to be adsorbed onto soil colloids, considering the soil depth of 0 to $20 \mathrm{~cm}$. In Oxisol samples, P affinity on colloid surfaces was reduced due to $\mathrm{BE}$ decrease.

Evaluating the interaction of $\mathrm{P}$ with goethite and hematite in a broad $\mathrm{pH}$ range (4.5 to 8), Wang et al. (2016) verified that HA reduced PMAC and P-BE. Polycarboxylic groups found in $\mathrm{HA}$ can inhibit $\mathrm{P}$ adsorption in tropical soil colloids by at least four different mechanisms: (i) blocking $\mathrm{P}$ binding sites; (ii) increasing the negative electric potential in the plane of adsorption; (iii) causing steric hindrance on the mineral surfaces (Fu et al., 2013; Wang et al., 2016); and (iv) decreasing goethite and hemathite specific surface area (Wang et al., 2016). These mechanisms reduce P affinity with the mineral surface of highly weathered soils, and may decrease soil $\mathrm{P}$ buffering capacity. 

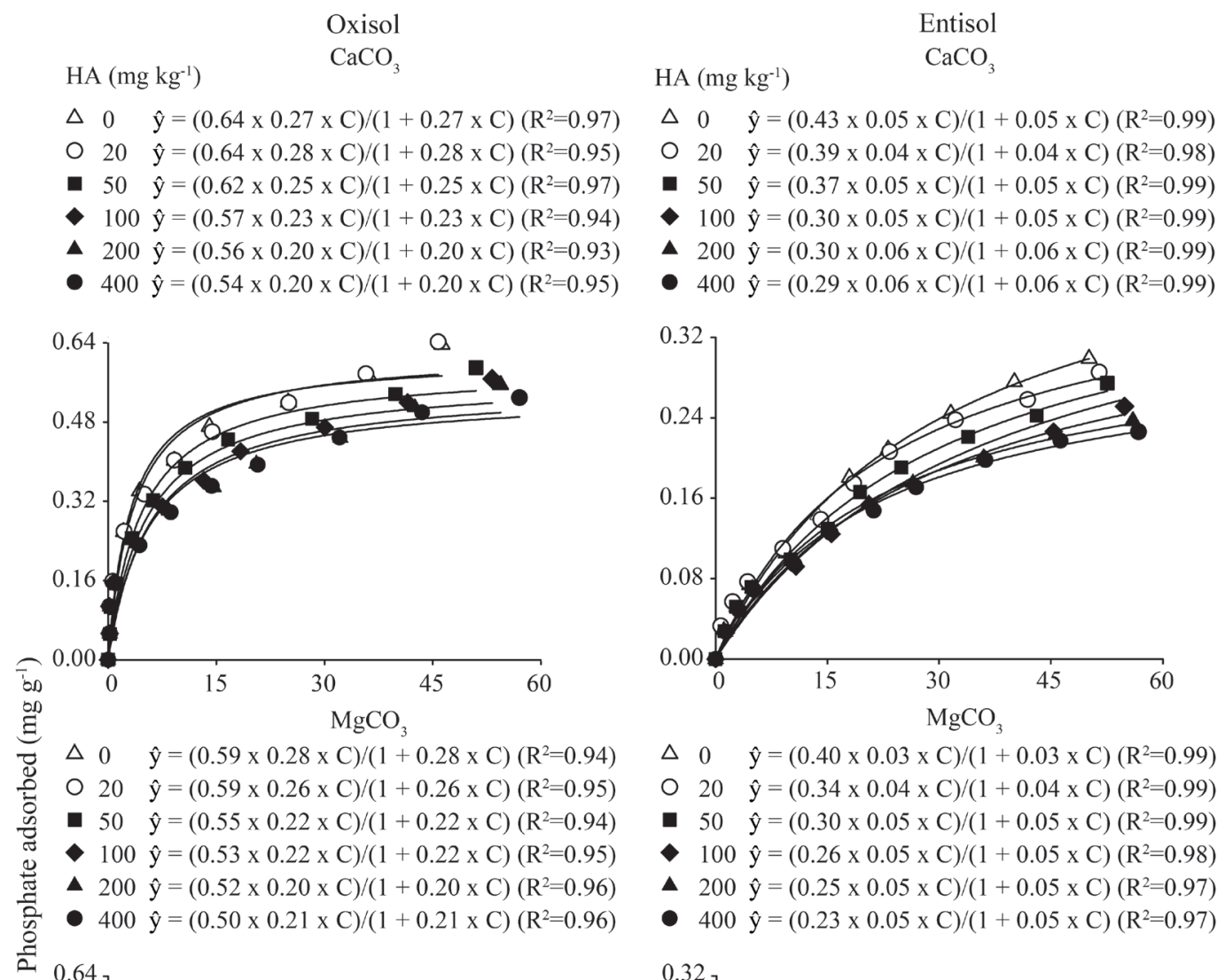

$\triangle 0 \quad \hat{\mathrm{y}}=(0.40 \times 0.03 \times \mathrm{C}) /(1+0.03 \times \mathrm{C})\left(\mathrm{R}^{2}=0.99\right)$

O $20 \hat{y}=(0.34 \times 0.04 \times C) /(1+0.04 \times C)\left(R^{2}=0.99\right)$

- $50 \hat{\mathrm{y}}=(0.30 \times 0.05 \times \mathrm{C}) /(1+0.05 \times \mathrm{C})\left(\mathrm{R}^{2}=0.99\right)$

- $100 \hat{\mathrm{y}}=(0.26 \times 0.05 \times \mathrm{C}) /(1+0.05 \times \mathrm{C})\left(\mathrm{R}^{2}=0.98\right)$

$\Delta 200 \hat{\mathrm{y}}=(0.25 \times 0.05 \times \mathrm{C}) /(1+0.05 \times \mathrm{C})\left(\mathrm{R}^{2}=0.97\right)$

- $400 \hat{y}=(0.23 \times 0.05 \times C) /(1+0.05 \times C)\left(R^{2}=0.97\right)$

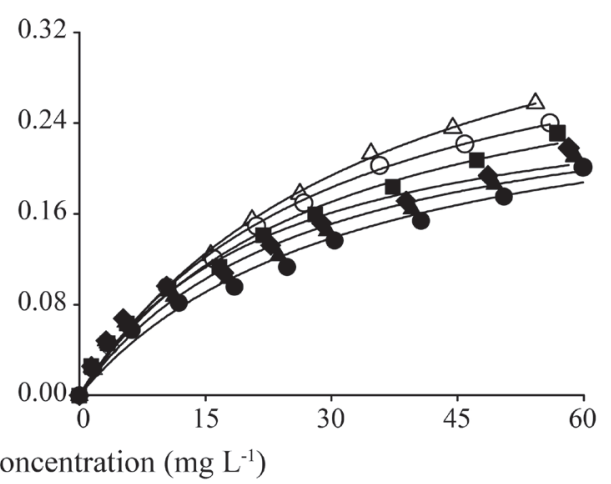

Figure 3: Phosphate adsorption isotherms adjusted to the Langmuir model for different humic acid (HA) rates added to the Oxisol and Entisol samples limed with $\mathrm{CaCO}_{3}$ or $\mathrm{MgCO}_{3}$.

PMBC is an index from which it is possible to infer soil resistance and rate to transfer $\mathrm{P}$ from solid to liquid phase, thus, it may be an indirect index of soil $\mathrm{P}$ availability (Novais; Smyth, 1999). PMBC was reduced over HA rates, with lesser values in Oxisol limed with $\mathrm{MgCO}_{3}$ than in sample treated with $\mathrm{CaCO}_{3}$, as it was verified for PMAC (Figure 4). In relation to the HA untreated soil samples, application of $296 \mathrm{mg} \mathrm{kg}^{-1} \mathrm{HA}$ reduced PMBC in $40 \%$. Therefore, not only the $\mathrm{P}$ adsorption in the Oxisol decreased, but also increased the ability of clayey soil to release $\mathrm{P}$ from mineral surfaces to soil solution, which reduces hysteresis or adsorption irreversibility.

Decrease in PMBC was also verified by Mejías, Alfaro and Harsh (2013), as the increase in P rate reduced the adsorption energy and enhanced $\mathrm{P}$ mobilization in a volcanic soil from Chile. Yu et al. (2013) also observed a reduction of $\mathrm{P}$ adsorption and $\mathrm{PMBC}$ by applying poultry manure in soil derived from basalt and incubated for up to 
60 days. Organic matter can act preventing P hysteresis and optimizing P fertilization in Brazilian soils (Guedes et al., 2016). Thus, results of this study have confirmed that soil $\mathrm{P}$ buffering capacity is a dynamic soil property, which is controlled by management and $\mathrm{C}$ fractions added to soil.

Analysis of Oxisol PMBC showed that, after the minimum value, PMBC tended to increase or even stabilize depending on the HA rate applied (Figure 4). Thus, increase of HA rates added to soil may also favor $\mathrm{P}$ sorption through the formation of HA-cation-P complexes (Guppy et al., 2005), preventing a linear decrease of Oxisol PMBC. Adsorption of organic anions on soil colloid surfaces can increase $\mathrm{P}$ adsorption through interactions of phosphate with $\mathrm{Ca}^{2+}$, reducing $\mathrm{P}$ mobility and availability (Weng; Riemsdijk; Hiemstra, 2012; Duputel et al., 2013). Thus, adding HA to Oxisol can either decrease or increase $\mathrm{P}$ adsorption, depending mainly on the HA rate added, exchangeable cation contents and organic-cation-P complexes formed in soil.

Organic-metallic-P complexes can be formed by different cations (Gerke, 2010), such as Fe, Al, Ca, and $\mathrm{Mg}$ with distinct chemical stability (Guppy et al., 2005; Urrutia et al., 2014). Jiang et al. (2015) verified that $\mathrm{Ca}^{2+}$ and $\mathrm{Mg}^{2+}$ from biochars increased the apparent adsorption of $\mathrm{P}$ in an Oxisol and an Ultisol. Association of cations with phosphate can occur on the mineral surface or in soil
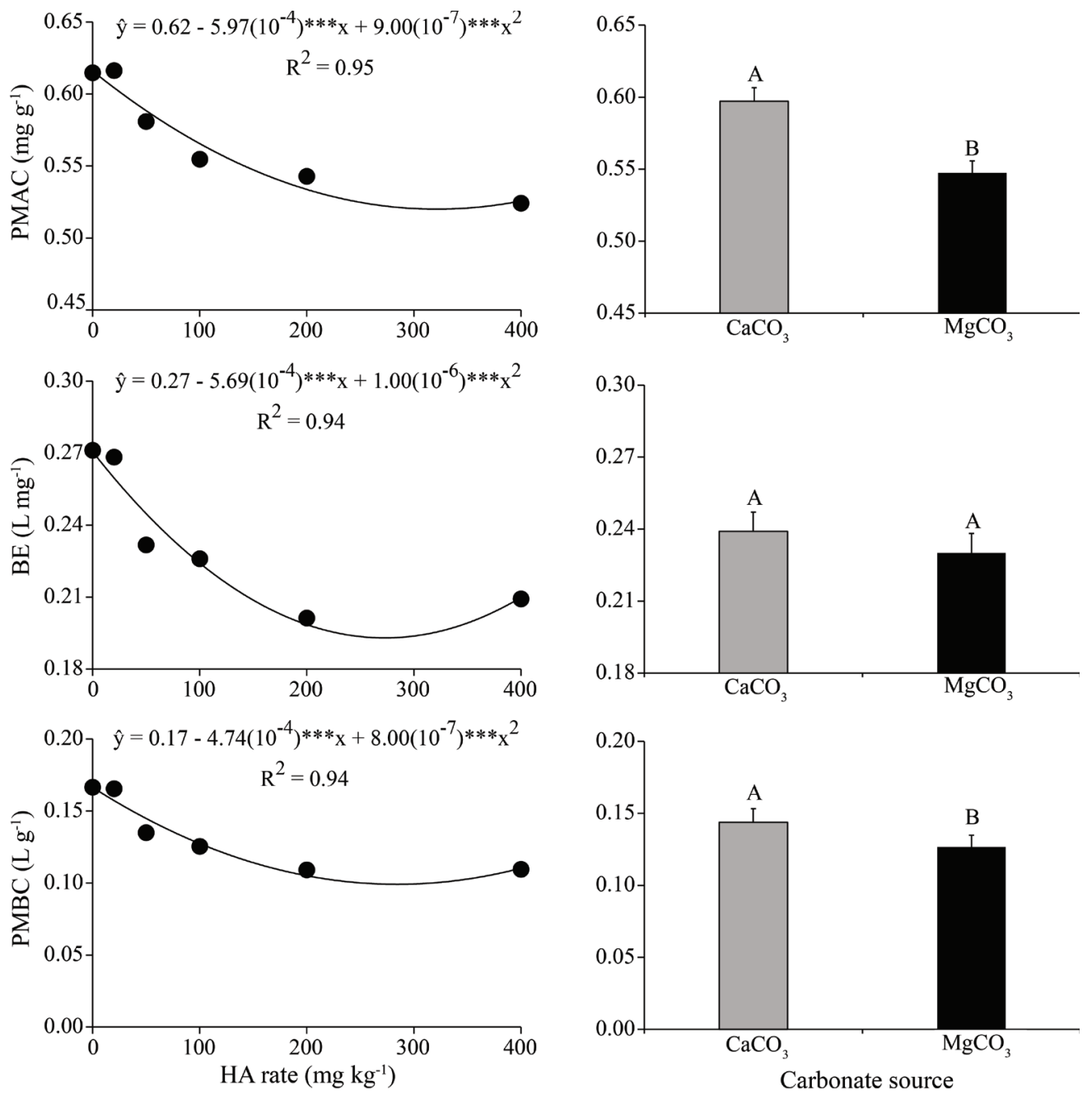

Figure 4: Phosphate maximum adsorption capacity (PMAC), binding energy (BE) and phosphate maximum buffering capacity (PMBC) of Oxisol samples affected by humic acid (HA) rates and carbonate sources. * $p<0.05$; $\star * p<0.01$; $* * * p<0.001$. Means followed by the same letter are not statistically different by the $\mathrm{F}$ test $(p<0.05)$. Bars represent the standard error of the mean. 
solution, through the formation of $\mathrm{MgPO}_{4}^{+}$or $\mathrm{CaPO}_{4}^{+}$ion pairs; these salts can be adsorbed in the negative charges of soil minerals or organic compounds; besides, the binding strength of $\mathrm{P}$ associated to $\mathrm{Ca}^{2+}$ is greater compared to $\mathrm{P}$ bonded to $\mathrm{Mg}^{2+}$ (Millero et al., 2001; Xu et al., 2014). In accordance with $\mathrm{Li}$ et al. (2016), association of $\mathrm{Ca}^{2+}$ to bentonite increased PMAC and P-BE in relation to $\mathrm{Mg}^{2+}$. Nevertheless, the formation of HA-cation-P complexes may be a strategy to assure better conditions for plant $\mathrm{P}$ uptake in soil. HA-metal-P complexes prevent phosphate to be specifically adsorbed onto mineral surfaces, since $\mathrm{P}$ tends to be slowly released into soil solution (Gerke, 2010).
In Entisol, PMAC decreased as HA rates increased, and the quadratic model was the equation that best fitted to data set (Figure 5). The lowest PMAC value was found when $275 \mathrm{mg} \mathrm{kg}^{-1} \mathrm{HA}$ was added to Entisol samples, which increased $\mathrm{P}$ in the equilibrium solution. However, $\mathrm{BE}$ increased up to $230 \mathrm{mg} \mathrm{kg}^{-1} \mathrm{HA}$, which $\mathrm{P}$ maximum binding energy to soil colloids was $26 \%$ greater than the soil non-treated with HA. Consequently, PMBC was not significantly affected by HA rates $(p=0.08)$, but, $\mathrm{CaCO}_{3}$ addition increased $\mathrm{PMBC}$ in relation to $\mathrm{MgCO}_{3}$, as was observed for the Oxisol samples. Yu et al. (2013) verified a similar result as PMAC decreased over poultry manure in
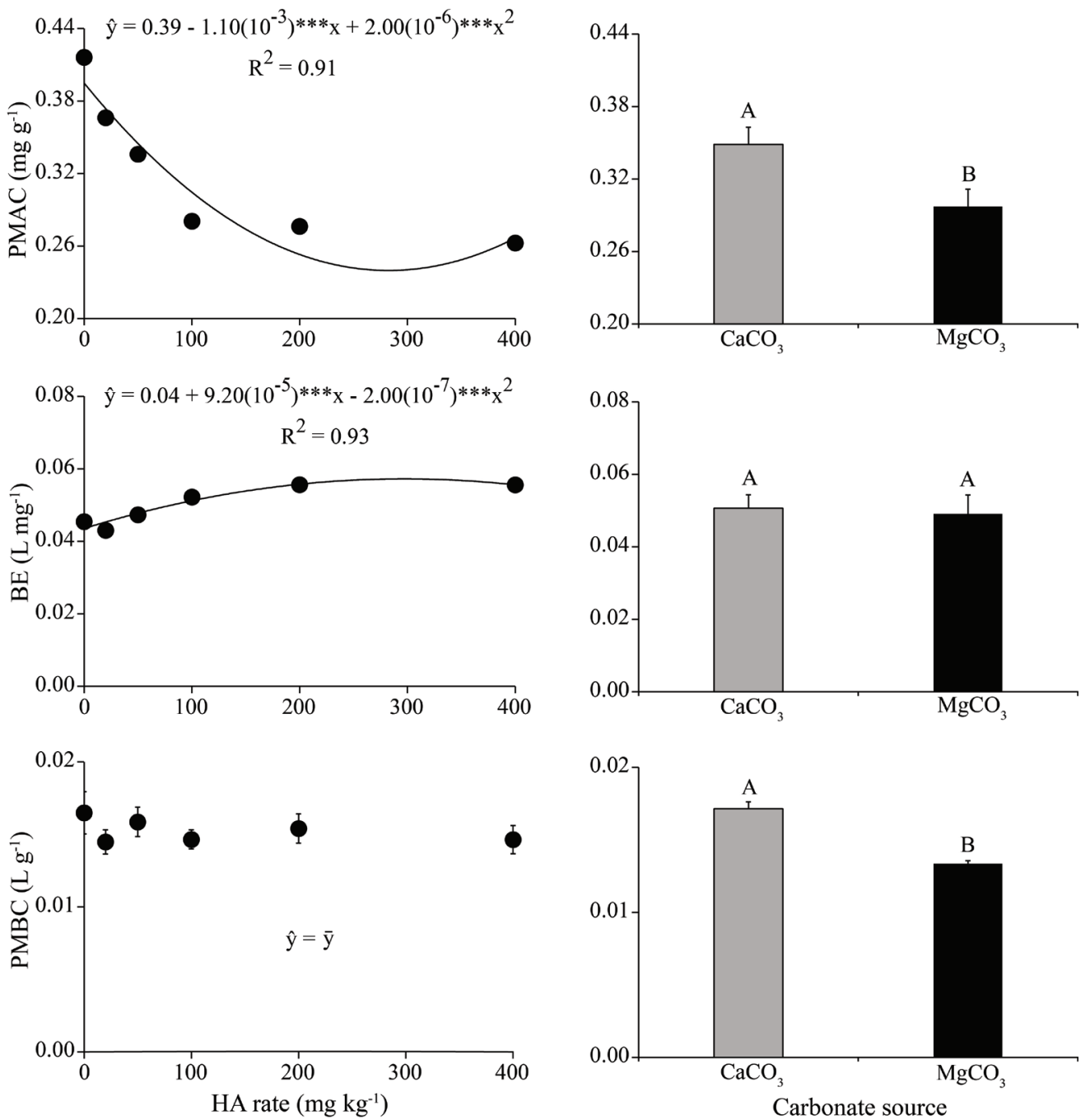

Figure 5: Phosphate maximum adsorption capacity (PMAC), binding energy (BE) and phosphate maximum buffering capacity (PMBC) of Entisol samples as related to humic acid (HA) rates and carbonate sources. * $p<0.05$; $\star * p<0.01$; $* * * p<0.001$. Means followed by the same letter are not statistically different by the $\mathrm{F}$ test $(p<0.05)$. Bars represent the standard error of the mean. 
soil derived from alluvium, and BE increased significantly after 30 days of incubation.

Absence of PMBC response over HA rates in Entisol is related to increase of BE (Figure 5) and it is linked to soil properties. The Entisol had half the clay content of the Oxisol (Table 1) and, therefore, the application of HA and P promoted increased competition between both anionic species for positively charged colloids. Theoretically, it is plausible to anticipate, without a prove of concept, that a possible interaction between HA and phosphate might have occurred. Initially, HA applied is preferentially adsorbed in soil colloids. However, with the addition of $\mathrm{P}$ (P adsorption study), competition for adsorption sites between HA and phosphate increases, probably causing displacement of the HA previously adsorbed.

Thereby, as P adsorbed on soil colloids and HA molecules around adsorption sites, colloids affinity for $\mathrm{P}$ is increased due to closeness of this anion with the adsorption plane, increasing BE to the extent that HA rates increased. Results found in this study are in accordance with Afif, Barrón and Torrent (1995), who verified that, in the presence of organic matter, colloid affinity for P in Brazilian soils is increased, with slow replacement of organic anions at the sorption sites. Therefore, it may be inferred that HA strongly competes for the same $\mathrm{P}$ binding site, and that the role played by HA in blocking P sorption is transient in the Entisol.

It should also be taken into account that interaction of HA to soil mineral constituents is weak through van der Waals forces, and it cannot effectively compete with P for soil colloids binding sites (Sibanda; Young, 1986). Furthermore, Lindegren and Persson (2009) reported that binding of carboxylic acids onto goethite does not occur through innersphere complexes. Guan, Shang and Chen (2006) examined the competitive adsorption between HA and P on the surface of synthetic aluminum hydroxide and found that HA added was completely adsorbed to the mineral, however, in the presence of $\mathrm{P}$, HA adsorption was reduced in up to $66 \%$.

\section{Phosphorus availability}

Available P contents in soils recovered by resin and Mehlich-1 soil tests were not altered by the HA rate-carbonate source interaction $(p>0.05)$, both in Oxisol (Figure 6) and in Entisol (Figure 7) samples. For Oxisol samples, soil P availability was influenced by HA rates. Resin-P contents reached the maximum value $\left(204 \mathrm{mg} \mathrm{kg}^{-1}\right)$ in Oxisol samples treated with $294 \mathrm{mg} \mathrm{kg}^{-1} \mathrm{HA}$, which represents an increase of $17 \%$ in soil resin-P content. Increase in P availability is associated to a decrease of $\mathrm{P}$ adsorption parameters (Figure 4). Mehlich-1 P (M1-P) contents were linearly increased over HA rates. Thus, maximum M1-P content $\left(99 \mathrm{mg} \mathrm{dm}^{3}\right)$ was verified at the rate of $400 \mathrm{mg} \mathrm{kg}^{-1} \mathrm{HA}$ in Oxisol samples. Differences between resin and M1-P contents are related to the reduced capacity of Mehlich-1 solution in recovering $\mathrm{P}$, mainly in high-clay-content soils (Novais; Smyth, 1999).

In an acid and weathered soil, Yang et al. (2013) observed that the combination of fulvic acid and $\mathrm{KH}_{2} \mathrm{PO}_{4}$ increased soil labile $\mathrm{P}$ extracted by $0.5 \mathrm{~mol} \mathrm{~L}^{-1} \mathrm{NaHCO}_{3}$. Increase of $\mathrm{P}$ availability after use of humic substances was verified by Hua et al. (2008) in Chinese soils. Even increasing soil $\mathrm{P}$ availability, optimum rate of humic substances to $\mathrm{P}$ availability in soils are not mentioned in the studies performed by Yang et al. (2013) and Hua et al. (2008). Optimum HA rate found in the present work for maximum P availability (Figure 6) may be prohibitive for
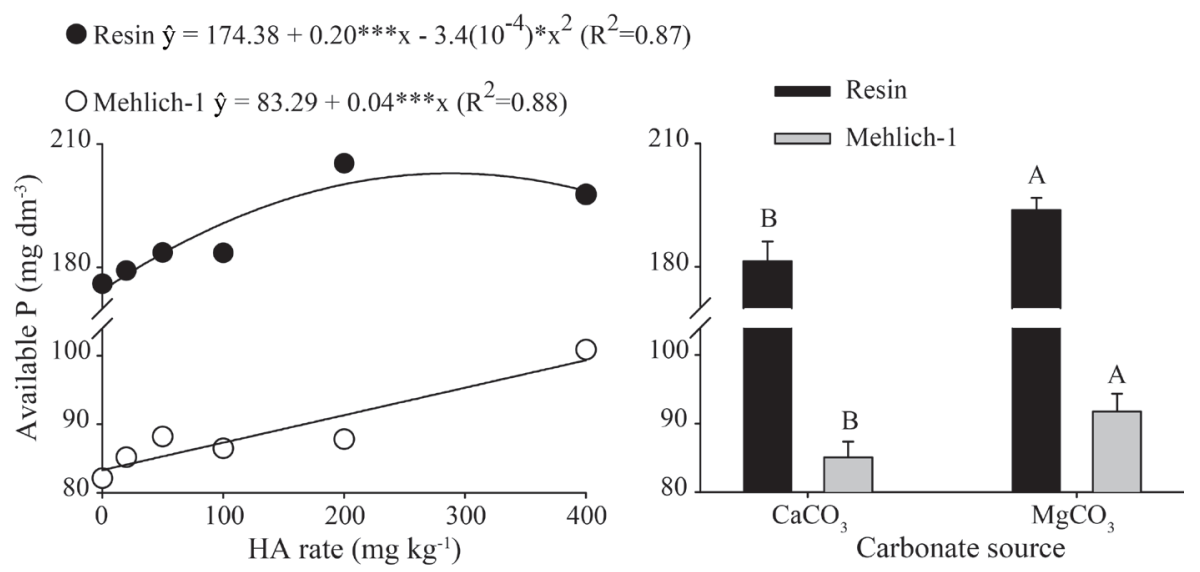

Figure 6: Resin-P and Mehlich-1 P contents in Oxisol samples treated with humic acid (HA) rates and carbonate sources. * $p<0.05$; ** $p<0.01$; *** $p<0.001$. Means followed by the same letter are not statistically different by the $\mathrm{F}$ test $(p<0.05)$. Bars represents the standard error of the mean. 

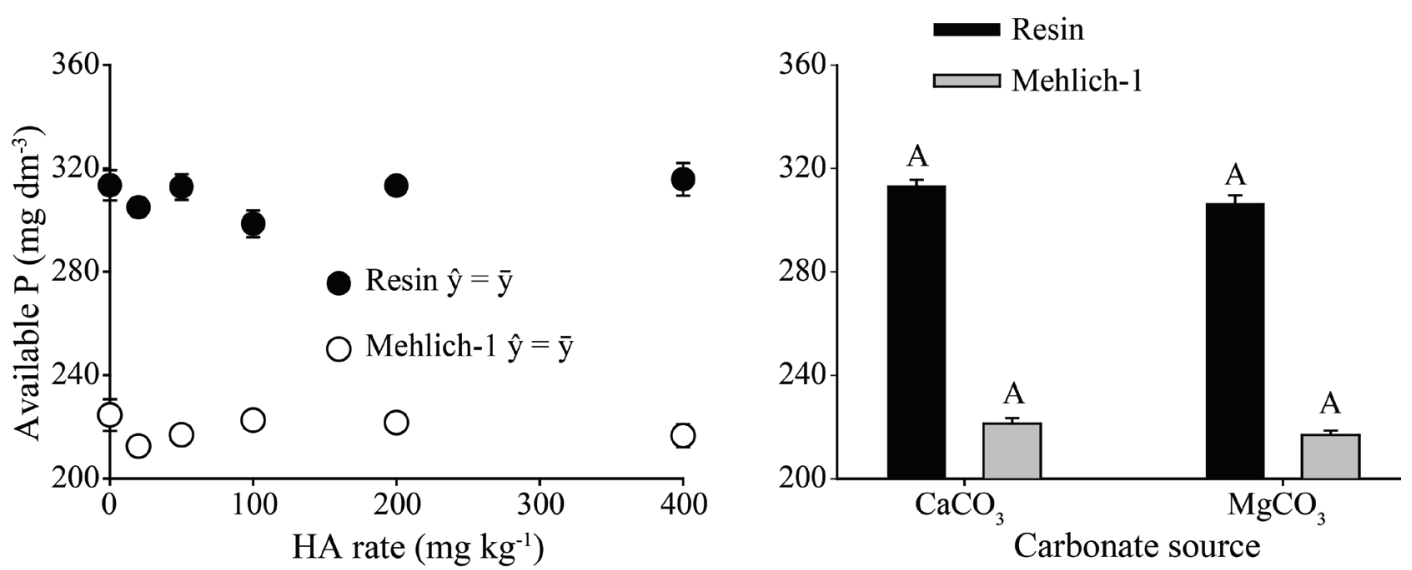

Figure 7: Resin-P and Mehlich-1 P contents in Entisol samples as related to humic acid (HA) rates and carbonate sources. Means followed by the same letter are not statistically different by the $\mathrm{F}$ test $(p<0.05)$. Bars represent the standard error of the mean.

some crop fields mainly where P-fertilizer is broadcasting applied. However, it may be feasible for some agricultural systems where HA is applied only in the soil volume under the influence of roots or in strip band or in row where $\mathrm{P}$ fertilizer is placed. Use of HA as an accompanying ligand to phosphate fertilizers may also be another strategy to prevent $\mathrm{P}$ fixation in highly weathered soils, which may optimize P-fertilizer use efficiency (Urrutia et al., 2014). Formulation of P-fertilizer with HA is a technology already used by the Brazilian fertilizer industry and incorporated in some crop fertilization programs (Herrera et al., 2016).

Greater resin- and M1-P contents were determined for Oxisol samples limed with $\mathrm{MgCO}_{3}$ than in those treated with $\mathrm{CaCO}_{3}$ (Figure 6). Hence, choosing the right source of lime materials $\left(\mathrm{CaCO}_{3}\right.$ or $\left.\mathrm{MgCO}_{3}\right)$ may alter both $\mathrm{P}$ adsorption and availability in soil, probably affecting $\mathrm{P}$ uptake by plants. In Entisol, neither effect of HA rates nor carbonate sources were observed for resin- or M1-P contents $(p>0.05)$ (Figure 7), which is partially related to the absence of PMBC response to HA rates in this soil (Figure 5). Thus, effects of HA rates on $\mathrm{P}$ adsorption and availability is soil-dependent, mainly relying on clay content and mineralogy. Herrera et al. (2016) verified that the application of single superphosphate complexed to HA did not alter resin-P contents in comparison to single superphosphate applied in non-HA treated soil with $22 \mathrm{~g} \mathrm{~kg}^{-1}$ of clay, under the effect of a rotation cropping system.

Significant and positive correlations were found between exchangeable $\mathrm{Ca}$ contents and $\mathrm{PMBC}$ for both Oxisol and Entisol samples limed with $\mathrm{CaCO}_{3}$ (Figure 8). This indicates that the higher $\mathrm{Ca}^{2+}$ content, the greater the soil resistance to release $\mathrm{P}$ from solid phase to soil solution.
However, there was not a significant correlation between exchangeable $\mathrm{Mg}$ contents and PMBC in both soils limed with $\mathrm{MgCO}_{3}$. Thus, $\mathrm{P}$-complexes are less stable with $\mathrm{Mg}$ than with Ca (Millero et al., 2001; Li et al., 2016), mainly, due to the largest ionic size of $\mathrm{Mg}$ in its hydrated form, which contributes to reduce P sorption (Xu et al., 2014).

Very few studies have reported the influence of HA rates on the adsorption and availability of $\mathrm{P}$ in weathered soils. Effect of carbonate accompanying cations $(\mathrm{Ca}$ or $\mathrm{Mg}$ ) on $\mathrm{P}$ adsorption is also lacking for highly weathered Brazilian soils. Greater contents of $\mathrm{Ca}^{2+}$ in soils increase the density of positive charges on the colloid surfaces, which result in increased $\mathrm{P}$ adsorption and a decrease in available $\mathrm{P}$ contents in comparison to $\mathrm{Mg}^{2+}$. Thus, the presence of $\mathrm{Mg}^{2+}$ in tropical soil play an important role to improve the efficiency use of P-fertilizers. Agronomically, $\mathrm{CaCO}_{3}$ can not replace $\mathrm{MgCO}_{3}$ in liming practices and, $\mathrm{Ca}$ and $\mathrm{Mg}$ must be added in adequate and balanced rates in soils. However, in crop fields where $\mathrm{CaCO}_{3}$ is successively applied over $\mathrm{MgCO}_{3}$, some effort should be made to apply $\mathrm{Mg}$ together with $\mathrm{P}$ source in order to meet crop $\mathrm{Mg}^{2+}$ requirement and to optimize agronomic performance of soluble P-fertilizers used in most Brazilian crop fields.

In future studies, adequate soil $\mathrm{Ca}: \mathrm{Mg}$ ratio which catalyzes the HA rates effect on decreasing $\mathrm{P}$ adsorption and increasing availability should be investigated. An ample variability of soil types, mineralogy, particle size distribution, and organic matter contents should be included in these experiments in order to understand the factors affecting P sorption, availability, forms and dynamics in tropical conditions, along with the role played by HA in optimizing P supplying to crops. 

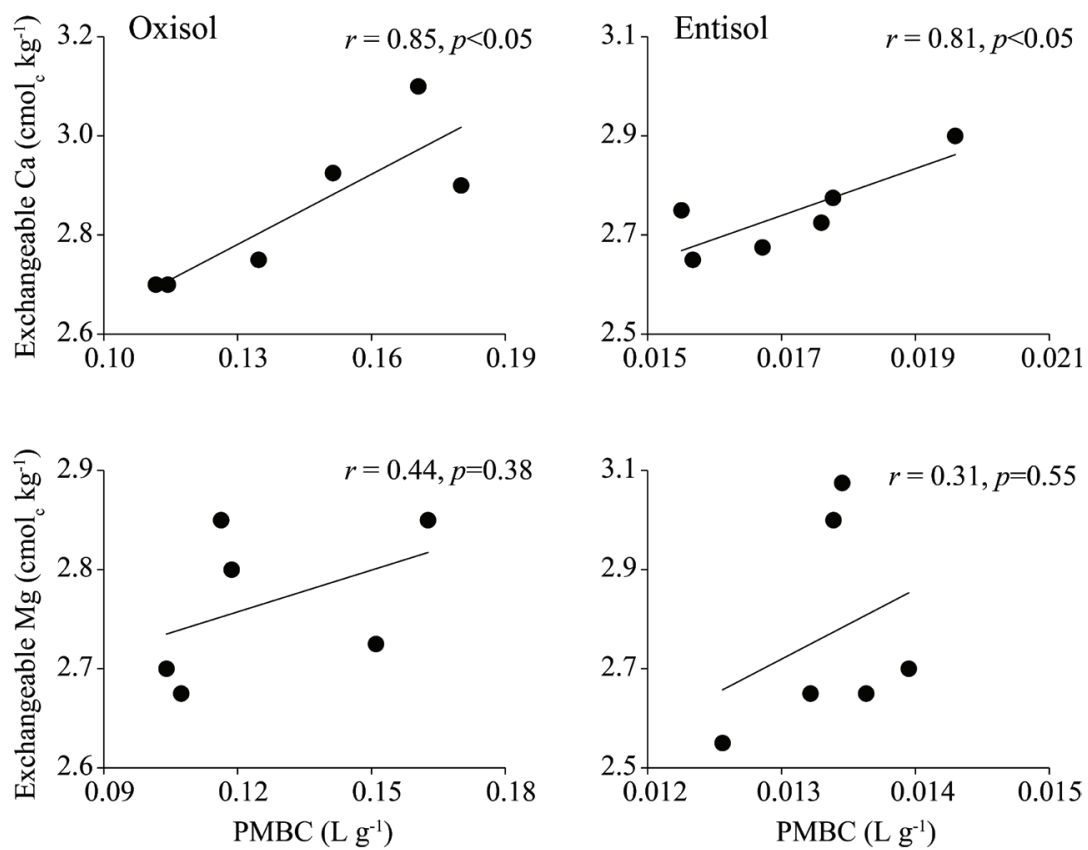

Figure 8: Linear correlations between exchangeable contents of Ca or $\mathrm{Mg}$ and phosphate maximum buffering capacity $(\mathrm{PMBC})$ for Oxisol and Entisol samples.

\section{CONCLUSIONS}

Humic acid rates and carbonate sources affected phosphate adsorption in Brazilian Oxisol and Entisol samples, and P availability only for the Oxisol samples. Choosing the adequate humic acid rate reduces $\mathrm{P}$ maximum adsorption capacity and binding energy on the colloid surfaces as well as decreases P maximum buffering capacity in the clayey Oxisol. Inhibition on $\mathrm{P}$ adsorption caused by the use of humic acid in the Oxisol increases $\mathrm{P}$ availability, with greater $P$ recovery by resin than by the Mehlich-1 soil test. Adding humic acid extracted from leonardite to clayey Brazilian Oxisols is an effective strategy to decrease $\mathrm{P}$ adsorption and increase soil $\mathrm{P}$ availability. Regardless of the humic acid rate added to soil, the preponderance of $\mathrm{Mg}^{2+}$ instead of $\mathrm{Ca}^{2+}$, only in soil volume fertilized with $\mathrm{P}$, is an option to decrease phosphate adsorption and buffering $\mathrm{P}$ capacity in both Oxisol and Entisol samples.

\section{ACKNOWLEDGMENTS}

Authors thank CAPES (PROEX-AUXPE 590/2014) for the scholarship, financial support provided for this work and covering of the costs of this publication. Our many thanks to FAPEMIG and CNPq (308592/20115, 461935/2014-7, and 303899/2015-8 grants) for financing part of the experimental costs and for providing scholarships to the authors of this study. We also acknowledge the help of Dr. Davi Lopes do Carmo who provided the soil samples. Many thanks to the Ph.D. student Giovana Clarice Poggere and to Professor Alberto Vasconcellos Inda for helping in the soil mineralogical analyses, and Dr. Zuy Maria Magriotis and Dr. Adelir Aparecida Saczk for supporting in the ATR-FTIR analysis of humic acid sample.

\section{REFERENCES}

AFIF, E.; BARRÓN, V.; TORRENT, J. Organic matter delays but does not prevent phosphate sorption by Cerrado soils from Brazil. Soil Science, 159(3):207-211, 1995.

ALVAREZ, V. V. H. et al. Determinação e uso do fósforo remanescente. Viçosa: SBCS, 2000. 32p. (Boletim Informativo, 25)

ATIYEH, R. M. et al. The influence of humic acids derived from earthworm-processed organic wastes on plant growth. Bioresource Technology, 84(1):7-14, 2002.

BENÍCIO, L. P. F. et al. Layered double hydroxides: New technology in phosphate fertilizers based on nanostructured materials. ACS Sustainable Chemistry \& Engineering, 5(1):399-409, 2017. 
DELGADO, A. et al. Phosphorus fertilizer recovery from calcareous soils amended with humic and fulvic acids. Plant and Soil, 245(2):277-286, 2002.

DUPUTEL, M. et al. Citrate adsorption can decrease soluble phosphate concentration in soils: Results of theoretical modeling. Applied Geochemistry, 35:120-131, 2013.

FERREIRA, E. B.; CAVALCANTI, P. P.; NOGUEIRA, D. A. ExpDes: Experimental designs package, version 1.1.2. 2013. Available in: <http://cran.r-project.org/web/packages/ ExpDes/index.html> Access in: May, 14, 2015.

FINK, J. R. et al. Mineralogy and phosphorus adsorption in soils of south and central-west Brazil under conventional and no-tillage systems. Acta Scientiarum-Agronomy, 36(3):379-387, 2014.

FU, Z. et al. Competitive interaction between soil-derived humic acid and phosphate on goethite. Applied Geochemistry, 36:125-131, 2013.

GERKE, J. Humic (organic matter)-Al(Fe)-phosphate complexes: An underestimated phosphate form in soils and source of plant-available phosphate. Soil Science, 175(9):417425, 2010.

GUAN, X. H.; SHANG, C.; CHEN, G.-H. Competitive adsorption of organic matter with phosphate on aluminum hydroxide. Journal of Colloid and Interface Science, 296(1):51-58, 2006.

GUEDES, R. S. et al. Adsorption and desorption kinetics and phosphorus hysteresis in highly weathered soil by stirred flow chamber experiment. Soil \& Tillage Research, 162:4654, 2016.

GUPPY, C. N. et al. Competitive sorption reactions between phosphorus and organic matter in soil: A review. Australian Journal of Soil Research, 43(2):189-202, 2005.

HERRERA, W. F. B. et al. Crop Yield and soil phosphorus lability under soluble and humic-complexed phosphate fertilizers. Agronomy Journal, 108(4):1-11, 2016.

HOLFORD, I. C. R.; MATTINGLY, G. E. G. Phosphate adsorption and availability plant of phosphate. Plant and Soil, 44(2):377-389, 1976.

HUA, Q. X. et al. Enhancement of phosphorus solubility by humic substances in ferrosols. Pedosphere, 18(4):533538, 2008.

KAMINSKI, J. et al. Estimativa da acidez potencial em solos e sua implicação no cálculo da necessidade de calcário. Revista Brasileira de Ciência do Solo, 26(4):1107-1113, 2002.
JIANG, J. et al. Mobilization of phosphate in variable-charge soils amended with biochars derived from crops straws. Soil \& Tillage Research, 146:139-147, 2015.

$\mathrm{LI}$, J. R. et al. Sequestration of naturally abundant seawater calcium and magnesium to enhance the adsorption capacity of bentonite toward environmental phosphate. Royal Society of Chemistry Advances, 6(28):2325223259, 2016.

LINDEGREN, M.; PERSSON, P. Competitive adsorption between phosphate and carboxylic acids: Quantitative effects and molecular mechanisms. European Journal of Soil Science, 60(6):982-993, 2009.

McKEAGUE, J. A. Manual on soil sampling and methods of analysis. Ottawa, Canadian Society of Soil Science, 1978. 212p.

MEHRA, O. P.; JACKSON, M. L. Iron oxide removal from soils and clay by a dithionite-citrate system bulfered with sodium bicarbonate. Clays and Clay Minerals, 7:317-327, 1960.

MEJÍAS, J. H.; ALFARO, M.; HARSH, J. Approaching environmental phosphorus limits on a volcanic soil of Southern Chile. Geoderma, 207-208:49-57, 2013.

MILLERO, F. et al. Adsorption and desorption of phosphate on calcite and aragonite in seawater. Aquatic Geochemistry, 7(1):33-56, 2001.

MURPHY, J.; RILEY, J. P. A modified single solution method for the determination of phosphate in natural waters. Analytica Chimica Acta, 27:31-36, 1962.

NOVAIS, R. F.; SMYTH, T. J. Fósforo em solo e planta em condições tropicais. Viçosa: Editora UFV, 1999. 399p.

PÁdUA, T. R. P.; SILVA, C. A.; MELO, L. C. A. Calagem em Latossolo sob influência de coberturas vegetais: Neutralização da acidez. Revista Brasileira de Ciência do Solo, 30(5):869-878, 2006.

PERASSI, I; BORGNINO, L. Adsorption and surface precipitation of phosphate onto $\mathrm{CaCO}_{3}$-montmorillonite: Effect of $\mathrm{pH}$, ionic strength and competitive with humic acid. Geoderma, 232-234:600-608, 2014.

RAIJ, B. van; QUAGGIO, J. A. Determinação de fósforo, cálcio, magnésio e potássio extraídos com resina trocadora de íons. In: RAIJ, B. VAN et al. Análise química para avaliação da fertilidade de solos tropicais. Campinas: APTA/IAC, 2001. p.189-199.

REDDY, S. et al. Elemental analysis, E4/E6 and total acidity of soil humic and fulvic acids from different land use systems. Annals of Plant and Soil Research, 16(2):89-92, 2014. 
SAMPAIO, J. A.; ALMEIDA, S. L. M. Calcário e Dolomito. In: LUZ, A. B.; LINS, F. A. F. Rochas e minerais industriais: Usos e especificações. Rio de Janeiro: CETEM/MCT, 2005. p.363-391.

SATO, S.; COMERFORD, N. B. Influence of soil pH on inorganic phosphorus sorption and desorption in a humid Brazilian Ultisol. Revista Brasileira de Ciência do Solo, 29(5):685694, 2005.

SIBANDA, H. M.; YOUNG, S. D. Competitive adsorption of humus acids and phosphate on goethite, gibbsite and two tropical soils. European Journal of Soil Science, 37(2):197-204, 1986.

SILVA, F. C. Manual de análises químicas de solos, plantas e fertilizantes. 2. ed. Brasília: Embrapa informação tecnológica, 2009. 627p.

STEVENSON, F. J. Humus chemistry: Genesis, composition, reaction. New York: John Wiley \& Sons, Inc., 1994. 496p.

SWIFT, R. S. Organic matter characterization. In: SPARKS, D. L. et al. Methods of soil analysis part 3: Chemical methods. Madison: SSSA, 1996. p.1011-1020.

TELES, A. P. B. et al. Do cover crops change the lability of phosphorus in a clayey subtropical soil under different phosphate fertilizers? Soil Use and Management, 33(1):3444, 2017.
URRUTIA, O. et al. Physico-chemical characterization of humicmetal-phosphate complexes and their potential application to the manufacture of new types of phosphate-based fertilizers. Journal of Plant Nutrition and Soil Science, 177(2):128-136, 2014.

VETTORI, L. Métodos de análises de solos. Rio de Janeiro: Ministério da Agricultura, 1969. 24p. (Boletim Técnico, 7)

WANG, H. et al. Phosphate adsorption on uncoated and humic acid-coated iron oxides. Journal of Soils and Sediments, 16(7):1911-1920, 2016.

WENG, L.; RIEMSDIJK, W. H. V.; HIEMSTRA, T. Factors controlling phosphate interaction with iron oxides. Journal of Environmental Quality, 41(3):628-635, 2012.

$X U, N$. et al. Mechanisms of phosphate retention by calcite: Effects of magnesium and $\mathrm{pH}$. Journal of Soils and Sediments, 14(3):495-503, 2014.

YANG, S. et al. Effect of fulvic acid on the phosphorus availability in acid soil. Journal of Soil Science and Plant Nutrition, 13(3):526-533, 2013.

YU, W. et al. Effects of organic-matter application on phosphorus adsorption of three soil parent materials. Journal of Soil Science and Plant Nutrition, 13(4):1003$1017,2013$. 